\title{
Evaluating the Role of Entrepreneurial Self-Efficacy on Entrepreneurial Intention of Tehran University (Case Study of Engineering Campus)
}

\author{
${ }^{*}$ Sara Khodabakhshi, Kambeiz Talebi \\ Faculty of Entrepreneurship, University of Tehran, Iran \\ *sarah.khodabakhshi@gmail.com
}

\begin{abstract}
Entrepreneurship is the engine of economics of human society. In most countries, entrepreneurship, and especially start up of new businesses is most essential matter. Intention to run business is the base of entrepreneurial action. People, who have entrepreneurial intention, expect to start businesses in the future. In this study, we evaluated the impact of entrepreneurial self-efficacy on entrepreneurial intention. Women entrepreneurship is very important economic matter. Today, many of developed and developing countries, focus on the importance of women entrepreneurship and the enterprises founded by them (GEM, 2010). In this study, we implemented two modified questionnaire: first; Shapero's entrepreneurial intention questionnaire (Shapero, 1982) and Entrepreneurial self-efficacy questionnaire (DeNoble, et al., 1999). In order to analyze gathered data, we used SPSS11 Software, regression and Coefficient. Result shows that entrepreneurial self-efficacy has positive effect on entrepreneurial intention.
\end{abstract}

Keywords: Entrepreneurship, Entrepreneurial intention, Entrepreneurial Self-Efficacy

\section{Introduction}

According Krueger (2000) intention is one of the most important factors for predicting human behaviors. Regarding the role of intention in human behaviors, different sciences also have examined this factor and came up with results. For example, in psychological researches, it has been proved that "intention" is the best and most proper predicting factor for planned human behaviors, especially for those behaviors that are rare, difficult to observe, or their fulfillment requires a long time or is not predictable (Ajzen, 1991; McMillan and Katz, 1992). In the areas of social psychology and marketing also the researchers have obtained significant success about using intention-based models for various uses, some of these issues are job preferences, weight loss, and using safety belt (Ajzen, 1991). Ajzen (1991) suggests that business establishment is a planned behavior, and therefore, intention-based models are also applicable here. Entrepreneurial intention, in general, is equal to the individual commitment to establish a business in a near future. Thus, according to the conducted studies we can say that people who have an entrepreneurial intention, (and as the intention is a good predicting factor) are likely to embark on job creation in a near future, will establish a business.

\section{Literature Review}

Due to the high importance of entrepreneurship as an effective strategy for countries' economical and social development, prediction of entrepreneurial activities is important in the societies. The studies found that status variables (such as employment status) or individual variables (such as sociological characteristics or personality characteristics) are weak predictors for entrepreneurial activities (Shaver and Scott, 1991).

Female Entrepreneurship: Female entrepreneurship is defined as: someone who alone or with contribution or with an inheritance, through creativity or innovation, has started or accepted a business and by accepting the social and administrative and finance and financial risks introduces new products to beat other competitors in the market (Robbins \& Langton, 1998).

Global Female Entrepreneurship Status: Women now comprise half of the 3.4 billion work force of the world. According to the Global Entrepreneurship Monitor (GEM) report in 2006 there were 7 female entrepreneurs out of every 100 people (Goulet, 1997). Female entrepreneurs in US created 9.1 million new jobs from 1997 to 2003 and caused the employment of 27.7 million people (Bhandari, 2006). Now, women own around 40 percent of the total jobs in private section and also 80 percent of hardworking workers are women who have made possible more than 3.6 trillion dollars of sales revenues (Grundstén, 
2004). In Britain the female entrepreneurship increased from 3.3 percent in 2003 to 3.9 percent in 2004 , and one in four women have debuted a new business (Robbins \& Langton, 1998). The growth rate of female entrepreneurs is more than the same rate among men (Bandura, 1986). Female entrepreneurs in Canada have a significant role in the economy of the country. From 1991 to 1999 the acceleration of businesses established by women was two times more than the acceleration of Canadian companies. These activities are increasingly growing in all states of Canada. The number of agencies owned by women is more than one-third of the businesses in this country and jobs are created for 1.7 million Canadians. The speed of work creation in the agencies owned by women is 13 percent, i.e. 4 times, more than the speed of work creation in total companies (Alvarez, 2005).

Definition of Intention: Regarding the definition of intention it can be concluded that intention, in fact, is the prelude to an action or a particular behavior that has been preplanned, and actually we can say that intention forms the human behaviors (Krueger, 2000). In general, most of the human behaviors are planned; creation of new businesses is usually evolved and fulfilled during time, and precise planning is essential for it. Studies show that even when people embark on entrepreneurship due to losing job, there has been evidence indicating tendency and interest in having a dependent business long time ago (Krueger, 2000). We will introduce intention and some of its most important models in the following sections.

Application of Entrepreneurial Intention Models Use: Considering the importance of intentions on behaviors in general, and on entrepreneurial behaviors in particular, several scholars have presented entrepreneurial intention models in order to be able to better predict entrepreneurial behaviors, among which Shapero's Entrepreneurial Event (SEE) model (1982) according to Krueger (2000) has received more statistical support compared to other models at its own time. Therefore it is considered by some scholars that Shapero's model appears slightly superior for assessing entrepreneurial intentions, especially compared to the "Theory of Planned behavior" of Ajzen (1987). Due to high importance of influence of entrepreneurial intention on entrepreneurial behaviors of individuals, many researchers have tried to offer entrepreneurial-intention-based models to predict entrepreneurial activities. For example, Krueger et al (2006) conducted a study on the students who were in the decision making stage of their career, using two Ajzen and Shapiro entrepreneurial-intention models (to be described later), that the results confirmed the application of the two models for predicting entrepreneurial activities. Intention-based models have other advantages that are described below:

- Intention-based models are an appropriate explanation for the question that why many of the entrepreneurs decide to establish a business long time before looking for the opportunities (Krueger et al., 2006).

- Understanding individuals' intention allows the researchers and scholars to be able to explain other phenomena related to entrepreneurship using it. For example, what does motivate search, and what is the source of ideas for creating a new business?

- Intention-based models can explain that how entrepreneurial education can form the individuals' intention for creating risky businesses, and consequently, we can design proper and purposeful educational programs (Fayolle et al., 2006).

- We can use Intention-based models for interpreting other strategic decisions, such as deciding on growing the business or getting out of it. Finally, administration researchers will be able to study the overlapping existing between intention of creating a risky business and recognizing the opportunity for a risky business (Krueger et al., 2006).

- The intention-based models not only help the researchers, but also allow the entrepreneurs to understand the reason behind particular decisions in the perspective of the new risky business.

Although, Shapero's model was the first intention-based model to be presented specifically for entrepreneurship, several other intention models have also been proposed. Among entrepreneurialintention-based models, two models of Shapiro Entrepreneurial Event Model (1982) and Ajzen Planned Behaviors Model (1987) are more applied and have been used in many studies. The effect of entrepreneurial self efficiency on entrepreneurial intention Self efficiency is the cognitive approach of individual about his/her abilities for mobilizing the resources, activities and motivations required for controlling the events of life. One of the important effects of self efficiency is individual's preference for performing particular behaviors (Chen et al., 1998). Self efficiency is associated with starting a particular behavior and insisting to do it in uncertain conditions, for determining higher objectives, and reducing the related threats' intensity (Bandura, 1982). This is important as it is said that recognizing opportunity depends on individual's condition recognition in control ability (Dutton, 1993) and self efficiency (Kruger 
\& Dicson, 1993). The notion of self efficiency that Bandura (1997) used to explain human behaviors equals "believing in individual's ability to organize and execute activities that are required to achieve a particular objective". In addition, self efficiency is known as the reliance of individual on his/her merits putting into practice, and also his/her judgment about "the extent of ability to react well facing upcoming events" (Bandura, 1982). In general, self efficiency is a motivating resource that depends on individual's confidence and belief in his/her capabilities to fulfill a task and can affect one's cognitive level (Van Oudenhoven and Van der Zee, 2002).

Formative Elements of Entrepreneurial Efficiency: General self-efficacy is an individual's faith in his or her capacity to perform successfully across a variety of diverse situations (Kristiansen and Indarti, 2004). Research into attitudes has found that one's perceptions of one's ability to perform specific tasks increase the likelihood of attitude converting into intent and consequent behavior (Ajzen, 1991). Boyd and Vozikis (1994) too, stated that self-efficacy is a valuable addition to entrepreneurial intentions models seeking to explain more about the development of entrepreneurial intentions. It follows that entrepreneurial behavior would be considered specific task behavior and that studies would be more reliable utilizing the task-specific construct. As the self efficiency notion relies on four fundamental information sources, which are interactive, it is dynamic and variant. These four sources as Lent et al (1996); Anderson and Betz (2001); Dey and Allen (2004) suggest are as follows:

- Persona achievements (successful experiences): successful and/or unsuccessful results in the past experiences affect individual's perception of self efficiency.

- Other's experiences (substitute experiences): seeing other's success enhances individual's self efficiency, conversely, seeing other's failure has negative effect on self efficiency.

- Oral persuasion: the encouragements and motivations of others can persuade the individual that she has the necessary capabilities to perform a task.

- Physiological and emotional stimulation: the physiological and emotional effects that one might experience while doing a task, such as anxiety, stress, and exhaustion can affect self efficiency.

Self efficiency and choosing a career: People choose professions that they feel they are good at, and avoid the jobs that they think they do not have required competency for it. People who believe that have the required competency for a job, are attracted to it, prepare themselves to perform it well, feel more commitment towards it, and are more likely to succeed in it (Lent et al., 1996; Bandura, 1982). Generally, people who exhibit more self efficiency have an innovative performance and find new opportunities in the jobs they pursue, because these people have higher objectives in mind, expect higher successes from themselves, have perseverance in solving problems and overcome career threats (Pinquart et al., 2003; Forbes, 2005). Therefore, it can be concluded that people who enjoy higher entrepreneurial self efficiency, tend to be more willing to take entrepreneurial jobs and as a result are more likely to have entrepreneurial intention.

Effect of entrepreneurial self efficiency on entrepreneurial intention: People who have a higher self efficiency find the business environment full of opportunities, while people who do not possess this quality find the same environment full of obstacles. Feasibility of task depends on the level of individual's perception of his/her ability to perform a task; therefore, individual's perception of a task's feasibility guides his/her in choosing a career (Krueger, 2000); since the same field of cognition makes performing a task possible or impossible. Self efficiency notion enhances feasibility. In this way individual's self efficiency notion affects positively his/her entrepreneurial intention (Krueger, 2000). A review of extant research on entrepreneurial alertness reveals that three schools of thought inform the construct's definitions: (1) the Austrian economic perspective, (2) the behavioral perspective, and (3) the cognitive perspective. The findings also show that entrepreneurial self efficiency is only true about entrepreneurs and therefore can be the distinctive factor between entrepreneurs and directors. This study assumes that entrepreneurial self efficiency influences the entrepreneurial intention of master degree students of Technical College of Tehran University. Kirzner (1973) takes an economics perspective, defining alertness as the ability to notice, without search, opportunities that have been overlooked.

\section{Methodology}

The methodology of this study involves mixed method approach, because the quantitative and qualitative data are collected simultaneously in order to show the homogeneity of the findings. The study is fundamental with respect to the objective. The conduct method consists of three parts. In the first stage, the study literature was reviewed and the existing models and theories in this area were identified and 
using research literature the questionnaire was designed. In the second stage, first the variables of intention and entrepreneurial self efficiency were measured using structured interview (based on questionnaire) by aid of categorical random sampling, and applying SPSS software the consistency between the variables of the research were examined. Finally, in the third stage, we reached conclusions using the data. In this research the entrepreneurial intention of the technical Bachelor's Degree girl students of Tehran University is considered the dependent variable and the entrepreneurial self efficiency is considered independent variable.

Population and Statistical Sample: The statistical sample of the study consists of the Bachelor's Degree girl students of who were studying (at the time of collecting the data of the questionnaire - i. e., second semester of educational year 2010-2011) at the Technical College of Tehran University. The total number of girl students of Technical College is estimated 600 people. According to Kokran formula, the sample size is 140 . Based on the opinion of the researcher 10 questionnaires were omitted and on the whole the data of 130 questionnaires were collected from the students.

\section{Results}

Table 1: The Number of Respondents Based According to Colleges

\begin{tabular}{lll}
\hline Campus & Field & Number of Women \\
\hline & Computer & 15 \\
& Electronic & 9 \\
Industry & 21 \\
Engineering & Mechanic & 12 \\
& Metallurgy & 9 \\
& Mining & 4 \\
& Computer Science & 15 \\
Total & Chemistry & 18 \\
& Civil & 27 \\
\hline
\end{tabular}

Reliability Variables of Study

Reliability of Entrepreneurial Self-Efficacy Variable: In the Questionnaire Twelve Questions was considered to Entrepreneurial Self-Efficacy Variable. The Cronbach's Alpha for this variable was 0.875 .

Table 2: The Cronbach's Alpha for Entrepreneurial Self-Efficacy (If Item deleted)

\begin{tabular}{llllll}
\hline & $\begin{array}{l}\text { Scale Mean if Item } \\
\text { Deleted }\end{array}$ & $\begin{array}{l}\text { Scale Variance } \\
\text { Item Deleted }\end{array}$ & $\begin{array}{l}\text { if } \\
\text { Torrected } \\
\text { Total Correlation }\end{array}$ & $\begin{array}{l}\text { Itembach's Alpha if } \\
\text { Item Deleted }\end{array}$ \\
\hline Q1 & 40.2172 & 44.517 & 0.598 & 0.863 \\
Q2 & 40.4034 & 45.425 & 0.488 & 0.870 \\
Q3 & 39.6310 & 46.068 & 0.525 & 0.868 \\
Q4 & 39.7310 & 45.983 & 0.487 & 0.870 \\
Q5 & 40.1552 & 41.156 & 0.708 & 0.855 \\
Q6 & 39.8172 & 44.427 & 0.644 & 0.861 \\
Q7 & 40.0310 & 43.726 & 0.633 & 0.861 \\
Q8 & 40.1759 & 42.429 & 0.701 & 0.856 \\
Q9 & 40.4966 & 45.877 & 0.424 & 0.874 \\
Q10 & 39.9862 & 48.173 & 0.265 & 0.882 \\
Q11 & 40.3621 & 42.592 & 0.658 & 0.859 \\
Q12 & 40.4138 & 42.672 & 0.651 & 0.860 \\
\hline
\end{tabular}

Reliability of Entrepreneurial Intention Variable: In the Questionnaire 8 Questions was considered to Entrepreneurial Intention Variable. The Cronbach Alpha for this variable was 0.671.

Analysis of entrepreneurial self-efficacy according to age: Minimum average of entrepreneurial selfefficacy was 1.73 and the maximum average was 5 (from 5). Data also shows that maximum average of entrepreneurial self-efficacy was within age range of 24-27. Age range of 21-24 was in the second place. 
Age range of 18-21, consisted -of youngest people of statistical sample, illustrated minimum amount of entrepreneurial self-efficacy.

Table 3: The Cronbach's Alpha for Entrepreneurial Intention (If Item deleted)

\begin{tabular}{|c|c|c|c|c|}
\hline & $\begin{array}{l}\text { Scale Mean if } \\
\text { Item Deleted }\end{array}$ & $\begin{array}{l}\text { Scale Variance if } \\
\text { Item Deleted }\end{array}$ & $\begin{array}{l}\text { Corrected Item- } \\
\text { Total Correlation }\end{array}$ & $\begin{array}{l}\text { Cronbach's Alpha if } \\
\text { Item Deleted }\end{array}$ \\
\hline Q14 & 27.7751 & 8.902 & 0.321 & 0.655 \\
\hline Q15 & 26.2071 & 8.951 & 0.504 & 0.610 \\
\hline Q16 & 25.5621 & 10.164 & 0.300 & 0.656 \\
\hline Q17 & 26.3195 & 9.088 & 0.388 & 0.635 \\
\hline Q18 & 26.0414 & 8.683 & 0.477 & 0.612 \\
\hline Q19 & 25.6509 & 9.586 & 0.386 & 0.638 \\
\hline Q20 & 27.3669 & 8.543 & 0.316 & 0.663 \\
\hline Q21 & 25.7811 & 9.648 & 0.287 & 0.658 \\
\hline
\end{tabular}

Analysis of Entrepreneurial Intention according age: about 39\% of respondents to questions, into question that measured their intention of establishing new businesses in 3 years later (Question 13) replied positively. This means $39 \%$ of statistical sample have entrepreneurial intention. If respondents replied positively to this question, they would answer to 8 questions about measuring entrepreneurial intention. Average of entrepreneurial intention of this students, had compared in table 4.

Table 4: Results of Entrepreneurial Intention According to age

\begin{tabular}{lllllllll}
\hline $\begin{array}{l}\text { Age } \\
\text { Range }\end{array}$ & Number & Mean & $\begin{array}{l}\text { Percent } \\
\text { Total Number) }\end{array}$ & $\begin{array}{l}\text { (From } \\
\text { S D }\end{array}$ & Minimum & Maximum & $\begin{array}{l}\text { Deviation of the } \\
\text { mean error }\end{array}$ \\
\hline $18-21$ & 23 & 3.73 & $46.2 \%$ & 0.38 & 2.88 & 4.50 & 0.04 \\
$21-24$ & 24 & 3.77 & $47.9 \%$ & 0.41 & 2.75 & 4.62 & 0.04 \\
$24-27$ & 3 & 3.97 & $5.9 \%$ & 0.74 & 2.88 & 5 & 0.23 \\
Total & 50 & 3.76 & $100 \%$ & 0.42 & 2.75 & 5 & 0.03 \\
\hline
\end{tabular}

Age range of 24-27, illustrated maximum average of entrepreneurial intention (3.97 from 5). Next place belonged to age range of 21-24 (3.77 from 5). And age range of 18-21 illustrated minimum amount of entrepreneurial intention.

Correlation between Entrepreneurial Self-Efficacy (Independent variable) and Entrepreneurial Intention (dependent variable): According to table 5, significant level of Correlation test (o.ooo) was lower than 0.05 errors; therefore $\mathrm{H0}$ was rejected. In other words, we can conclude that with $95 \%$ confidence, there are correlation between Entrepreneurial Self-Efficacy and Entrepreneurial Intention.

Table 5: Results of Correlation between Entrepreneurial Self-Efficacy and Entrepreneurial Intention

\begin{tabular}{lllllll}
\hline Hypothesis & $\begin{array}{l}\text { Independent } \\
\text { Variable }\end{array}$ & $\begin{array}{l}\text { Dependent } \\
\text { Variable }\end{array}$ & $\begin{array}{l}\text { Correlation } \\
\text { Coefficient }\end{array}$ & $\begin{array}{l}\text { Significant } \\
\text { level }\end{array}$ & $\begin{array}{l}\text { Error } \\
\text { rate }\end{array}$ & Results \\
\hline $\mathbf{1}$ & $\begin{array}{l}\text { Entrepreneuri } \\
\text { al Self-Efficacy }\end{array}$ & $\begin{array}{l}\text { Entrepreneur } \\
\text { ial Intention }\end{array}$ & 0.364 & 0.000 & 0.01 & $\begin{array}{l}\text { H0 } \\
\text { Rejected }\end{array}$ \\
\hline
\end{tabular}

After proving correlation between dependent and independent variable, we can survey linear relationship. This mentioned on table 6 that devoted to regression test.

Table 6: Results of Linear Relationship between Entrepreneurial Self-Efficacy and Entrepreneurial Intention

\begin{tabular}{llllllll}
\hline Hypothesis & Ho & B & Beta & $\begin{array}{l}\text { T } \\
\text { Value }\end{array}$ & Sig & $\begin{array}{l}\text { Error } \\
\text { rate }\end{array}$ & Results \\
\hline \multirow{2}{*}{1} & $\begin{array}{l}\text { There is no Linear relationship } \\
\text { between Entrepreneurial Self-Efficacy } \\
\text { and Entrepreneurial Intention }\end{array}$ & 0.30 & 0.364 & 5.053 & 0.00 & 0.01 & $\begin{array}{l}\text { H0 } \\
\text { Rejected } \\
\text { Fixed Value }\end{array}$ \\
\hline
\end{tabular}


According to table 7, significant level of regression test (0.000) was lower than 0.05 error, and therefore linear relationship between variables was approved. Therefore, we can conclude that with 95\% confidence, there are linear relationship between Entrepreneurial Self-Efficacy and Entrepreneurial Intention.

\begin{tabular}{ll} 
Table 7: Friedman Test in order to explore Factors related to Entrepreneurial Self-Efficacy \\
\hline Factors related to Entrepreneurial Self-Efficacy & Mean value \\
New product development and market opportunities & 3.07 \\
Dealing with unexpected challenges & 4.47 \\
Development of human resources & 3.91 \\
Determination of critical goals & 3.53 \\
Development of innovative environment & 2.94 \\
Establishing relationships with Owners of capital & 3.08 \\
\hline
\end{tabular}

\section{Conclusion}

Entrepreneurial Self-Efficacy has positive effect on Entrepreneurial Intention of female students of engineering campus of university of Tehran. Based on correlation test (significant and 0.387), we can conclude that entrepreneurial self-efficacy has positive and significant effect on entrepreneurial intention of statistical sample. This means, every enhancement in entrepreneurial self-efficacy, have positive effect on enhancement of entrepreneurial intention of students. Therefore, we can conclude that if a person possesses high entrepreneurial self-efficacy, this means he believe that he has necessary ability t being an entrepreneur and therefore he can do entrepreneurial rules and tasks successfully. As a result, selfefficacy belief, increases perception of feasibility at the person, and therefore influences on entrepreneurial intention. Future researches can be performed into subjects such as "how self-efficacy created and enhanced in persons". Also, comparison of entrepreneurial intention and self-efficacy of male and female students, or comparison of these variables on other campuses, can be analyzed on future researches in order to achieving comprehensive results.

\section{References}

Alvarez, S. (2005). Theories of Entrepreneurship: alternative assumptions and the study of entrepreneurial action. MA: Now Publishers Inc.

Ajzen, I. (1987). Attitudes, traits, and actions: Dispositional prediction of behavior in personality and social psychology. Advances in Experimental Social Psychology, 20, 1-63.

Ajzen, I. (1991). Theory of planned behavior. Organizational Behavior and Human Decision Processes, $50,179-211$

Anderson, S. L., \& Betz, N. E. (2001). Sources of social self-efficacy expectations: their measurement and relation to career development. Journal of Vocational Behavior, 58(1), 98-117.

Boyd, N. G., \& Vozikis, G. S. (1994). The Influence of Self-Efficacy on the Development of Entrepreneurial Intentions and Actions. Entrepreneurship: Theory and Practice, 18(4).

Bandura, A. (1982). Self-efficacy mechanism in human agency. American Psychologist, 37(2), 122-147.

Bandura, A. (1986). Social foundations of thought and action: A social cognitive theory. Prentice-Hall, Inc.

Bhandari, N. C. (2006). Intention for Entrepreneurship among Students in India. Journal of Entrepreneurship, 15(2), 169.

Bandura, A. (1997). Self-efficacy: The exercise of control. New York: Freeman.

Bhandari, N. (2006). Intention for Entrepreneurship among students of India. The Journal of Entrepreneurship, 15(1).

Chen, C. C., Greene, P. G., \& Crick, A. (1998). Does entrepreneurial self-efficacy distinguish entrepreneurs from managers? Journal of Business Venturing, 13(4), 295-316.

Day, R., \& Allen, T. D. (2004). The relationship between career motivation and self-efficacy with protégé career success. Journal of Vocational Behavior, 64(1), 72-91.

DeNoble, A. F., Jung, D., \& Ehrlich, B. (1999). Entrepreneurial Self-Efficacy: The Development of a Measure and Its Relationship to Entrepreneurial Action. Babson College.

Dutton, J. E. (1993). Interpretations on automatic: A different view of strategic issue diagnosis. The Journal of Management Studies, 30, 339-357.

Fayolle, A., Gailly, B., \& Lassas-Clerc, N. (2006). Assessing the impact of entrepreneurship education programs: a new methodology. Entrepreneurship Education Programs, 30, 701-720. 
Forbes, D. P. (2005). The effects of strategic decision making on entrepreneurial self-efficacy. Entrepreneurship Theory and Practice, 29(5), 599-626.

Global Entrepreneurship Monitor, Global 2010 Executive Report, (Accessed http://www.gemconsortium.org/category_list.asp?cid=179. October 2, 2011).

Goulet, L. R. (1997). Modeling aggression in the workplace: The role of role models. Academy of Management Executive, 11(2), 84-86.

Grundstén, H. (2004). Entrepreneurial Intentions and the Entrepreneurial Environment. A Study of Technology-Based New Venture Creation. Doctoral dissertation. Helsinki University of Technology, Finland.

Hsu, M. H., \& Chiu, C. M. (2004). Internet self-efficacy and electronic service acceptance. Decision Support Systems, 38(3), 369-381.

Kirzner, I. M. (1973). Competition and entrepreneurship. Chicago: University of Chicago Press.

Kristiansen, S., \& Indarti, N. (2004). Entrepreneurial intention among Indonesian and Norwegian students. Journal of Enterprising Culture, 12(1), 55-78.

Krueger, N., \& Dickson, P. (1993). Perceived self-efficacy and perceptions of opportunity and threat. Psychological Reports, 72, 1235-1240.

Krueger, N. F., Reilly, M. D., \& Carsrud, A. L. (2000). Competing models of entrepreneurial intentions. Journal of Business Venturing, 15, 411-432.

Krueger, N., \& Kickul, J. (2006). So you thought the intentions model was simple. In Navigating the Complexities and Interactions of Cognitive Style, Culture, Gender, Social Norms, and Intensity on the Pathways to Entrepreneurship, USASBE conference, Tuscon, AZ.

Lent, R. W., Lopez, F. G., Brown, S. D., \& Gore, P. A. (1996). Latent structure of the sources of mathematics self-efficacy. Journal of Vocational Behavior, 49(3), 292-308.

McMillan, I., \& Katz, J. (1992). Idiosyncratic milieus of entrepreneurship research: The need for comprehensive theories. Journal of Business Venturing, 7, 1-8.

Pinquart, M., Juang, L. P., \& Silbereisen, R. K. (2003). Self-efficacy and successful school-to-work transition: A longitudinal study. Journal of Vocational Behavior, 63(3), 329-346.

Robbins, S. P., \& Langton, N. (1998). Organizational behavior: Concepts, controversies, and applications. Prentice Hall Upper Saddle River, New Jersey.

Shapero A. (1982). Social Dimensions of Entrepreneurship. In C. Kent, D. Sexton and K. Vesper, eds., the Encyclopedia of Entrepreneurship. Englewood Cliffs: Prentice-Hall, 72-90.

Shaver, K. G., \& Scott, L. R. (1991). Persons, Process, Choice: The psychology of New Venture Creation. Entrepreneurship Theory and Practice.

Van Oudenhoven, J. P., \& Van der Zee, K. I. (2002). Predicting multicultural effectiveness of international students: The Multicultural Personality Questionnaire. International Journal of Intercultural Relations, 26(6), 679-694. 